University of Nebraska - Lincoln

DigitalCommons@University of Nebraska - Lincoln

Faculty Publications from the Harold W. Manter Laboratory of Parasitology

4-1996

\title{
Two New Species of Tetraphyllidean Cestodes in Himantura pacifica (Chondrichthyes: Myliobatiformes: Dasyatididae) from the Northwest Coast of Costa Rica
}

\author{
Fernando Marques \\ University of Toronto \\ Daniel R. Brooks \\ University of Toronto,dnlbrooks@gmail.com \\ Helena Molina Ureña \\ Universidad de Costa Rica
}

Follow this and additional works at: https://digitalcommons.unl.edu/parasitologyfacpubs

Part of the Parasitology Commons

Marques, Fernando; Brooks, Daniel R.; and Molina Ureña, Helena, "Two New Species of Tetraphyllidean Cestodes in Himantura pacifica (Chondrichthyes: Myliobatiformes: Dasyatididae) from the Northwest Coast of Costa Rica" (1996). Faculty Publications from the Harold W. Manter Laboratory of Parasitology. 273.

https://digitalcommons.unl.edu/parasitologyfacpubs/273

This Article is brought to you for free and open access by the Parasitology, Harold W. Manter Laboratory of at DigitalCommons@University of Nebraska - Lincoln. It has been accepted for inclusion in Faculty Publications from the Harold W. Manter Laboratory of Parasitology by an authorized administrator of DigitalCommons@University of Nebraska - Lincoln. 


\title{
TWO NEW SPECIES OF TETRAPHYLLIDEAN CESTODES IN HIMANTURA PACIFICA (CHONDRICHTHYES: MYLIOBATIFORMES: DASYATIDIDAE) FROM THE NORTHWEST COAST OF COSTA RICA
}

\author{
Fernando Marques, Daniel R. Brooks, and Helena Molina Ureña* \\ Department of Zoology, University of Toronto, Toronto, Ontario, Canada M5S 1A1
}

\begin{abstract}
Two new species of tetraphyllidean cestodes inhabiting Himantura pacifica from the northwest coast of Costa Rica are apparently most closely related to species inhabiting Himantura schmardae from the Atlantic coast of Colombia. Acanthobothroides pacificus $\mathrm{n}$. sp. differs from Acanthobothroides thorsoni, the only other species in the genus, primarily by having smaller lateral (98-123 $\mu \mathrm{m}$ rather than 168-198 $\mu \mathrm{m}$ long) and medial (handles 92-116 $\mu \mathrm{m}$ rather than 162-168 $\mu \mathrm{m}$ long) hooks, and more testes (up to 125 rather than up to 97) per proglottis. The generic diagnosis of Acanthobothroides is modified to include the presence of a small inner prong on the large medial bothridial hooks. Rhinebothrium geminum n. sp. and Rhinebothrium magniphallum are the only 2 species in the genus possessing unusually long cirrus sacs, extending from the genital atrium all the way to the ovarian isthmus; $R$. geminum averages $12(12-14)$ loculi per bothridium and $11(9-12)$ testes, whereas $R$. magniphallum averages $17(16-18)$ loculi and $14(10-16)$ testes per proglottis.
\end{abstract}

The presence of sister species on each side of the Panama isthmus has been reported for octopods, sea urchins, pinnotherid crabs of the genus Dissodactylus, and atherinid fishes (Voight, 1988; Lessios, 1979; Griffith, 1987; White, 1986) among others. However, studies referring to pairs of species on both side of the isthmus are scarce for helminths, restricted to Manter's (1940) list of species pairs of digenetic trematodes inhabiting marine fishes. Brooks (1977) described 6 new species of tetraphyllidean cestodes inhabiting a species of marine stingray, Himantura schmardae (Werner), from the Caribbean coast of Colombia. The present paper describes 2 new species of tetraphyllideans inhabiting the putative sister species of $\mathrm{H}$. schmardae, Himantura pacifica (Beebe and Tee-Van), from the Pacific coast of Costa Rica.

\section{MATERIALS AND METHODS}

In June 1992, 1 specimen of Himantura pacifica (Beebe and TeeVan) was captured at Playa Panama, Guanacaste Province, Costa Rica, using a beach seine. Worms were removed from the spiral valve, killed with hot tap water, transferred immediately to AFA for $24-48 \mathrm{hr}$, and then stored in $70 \%$ ethanol. Specimens were stained with Mayer's hematoxylin and mounted in Canada balsam for examination as whole mounts. Measurements are in $\mu \mathrm{m}$ unless otherwise stated; for some traits, ranges are given, followed in parentheses by mean values \pm 1 standard deviation and the sample size (n). Hook measurements follow the formula of Euzet (1956) modified as follows: For each parameter, mean value \pm 1 standard deviation is given, followed in parentheses by its range. Figures were drawn with the aid of camera lucida using a BH-2 Olympus microscope. The tetralobed nature of the ovaries was confirmed from lateral views of unmounted specimens and from whole mounts because sufficient material for sectioning was not available. MNHG refers to the Museum of Natural History, Geneva, Switzerland; USNPC refers to the U.S. National Parasite Collection, Beltsville, Maryland; UNSMHWML refers to the University of Nebraska State Museum, Harold W. Manter Laboratory, Division of Parasitology, Lincoln, Nebraska, U.S.A.

Received 10 July 1995; revised 30 October 1995; accepted 30 October 1995.

* Escuela de Biologia, Universidad de Costa Rica, San José, Costa Rica.

\section{DESCRIPTION \\ Acanthobothroides pacificus n. sp. (Fig. 1A-D)}

Description (based on 2 complete and 2 incomplete specimens): Strobila craspedote, anapolytic, up to 65.3-122 mm long; composed of up to 409 proglottides. Scolex $719-954(n=2)$ long by $935-1,078(n=2)$ wide. Bothridia 630-814 (716 $\pm 67 ; n=7)$ long by 324-445 (383 \pm $38 ; n=7)$ wide; anterior loculus 394-464 (422 $\pm 30 ; n=7)$ long, middle loculus 140-197 (169 $\pm 19 ; n=7)$, posterior loculus 89-159 (124 \pm $22 ; n=7)$. Ratio of loculi lengths $1: 0.4: 0.3$. Bothridial apical suckers 63-79 (70 $\pm 7 ; \mathrm{n}=6)$ in diameter, pads $173-198(182 \pm 12 ; \mathrm{n}=5)$. Medial bothridial hooks 100-131 (120 $\pm 10 ; n=6)$ long; handle 92$116(106 \pm 9 ; n=7)$ long, inner prong 41-54 (47 $\pm 4, n=7)$, outer prong 66-82 $(77 \pm 7, \mathrm{n}=7)$. Lateral bothridial hooks 98-123 (109 \pm $11 ; n=7)$ long; handle 64-79 $(71 \pm 4 ; n=7)$, inner prong 43-57 (51 $\pm 5 ; n=7)$, outer prong 59-71 $(64 \pm 4 ; n=7)$. Cephalic peduncle 5.8 $26.8(16.0 \pm 9.0 ; \mathrm{n}=4) \mathrm{mm}$ long. Immature proglottides wider than long. Mature proglottides 394-604 $(488 \pm 61 ; n=14)$ long by $1.28-$ $1.70(1.53 \pm 0.15 ; \mathrm{n}=14) \mathrm{mm}$ wide. Testes $80-125(104 \pm 13 ; \mathrm{n}=$ $14)$ in number, 43-101 $(77 \pm 11 ; \mathrm{n}=100)$ in diameter, $11-20(15 \pm$ $3 ; n=14)$ postporally, 23-39 $(33 \pm 6 ; n=14)$ preporally, 46-69 (57 $\pm 6 ; n=14)$ antiporally. Cirrus sac near mid-proglottis, 337-445 (401 $\pm 24 ; n=41)$ long by $146-223(188 \pm 20 ; n=41)$ wide, contained spined eversible cirrus. Vagina anterior to cirrus sac; vaginal sphincter a muscular-glandular thickening near genital pore. Proglottides not containing testes, but with sperm in the vas deferens $0.46-1.37(0.85 \pm$ $0.26 ; \mathrm{n}=17) \mathrm{mm}$ long by $0.67-1.62(1.15 \pm 0.27 ; \mathrm{n}=17) \mathrm{mm}$ wide Genital pore $43-53 \%(46 \pm 3 ; n=19)$ of proglottis length from anterior end. Ovary follicular $305-420(373 \pm 48 ; n=7)$ long by $922-1,049$ $(998 \pm 46 ; n=7)$ wide at isthmus. Isthmus $69-176(115 \pm 2 ; n=12)$ long by $66-108(99 \pm 20 ; n=12)$ wide. Vitelline follicles extending entire length of proglottis, from level of ovarian isthmus to near anterior end. Uterus not observed.

\section{Taxonomic summary}

Host: Himantura pacifica (Beebe and Tee-Van).

Site of infection: Spiral valve.

Locality: Playa Panama, Guanacaste, Costa Rica $\left(10^{\circ} 15^{\prime} \mathrm{N} ; 86^{\circ} 00^{\prime} \mathrm{W}\right)$.

Holotype: MNHG no. INV 20585.

Paratypes: MNHG no. INV 20586; UNSMHWML no. 38742.

Etymology: The species is named for the ocean from which it was first described.

\section{Remarks}

Acanthobothroides was proposed by Brooks (1977) for A. thorsoni Brooks, 1977 collected in the spiral valve of $H$. schmardae from the Atlantic coast of Colombia. Acanthobothroides thorsoni possessed sco- 

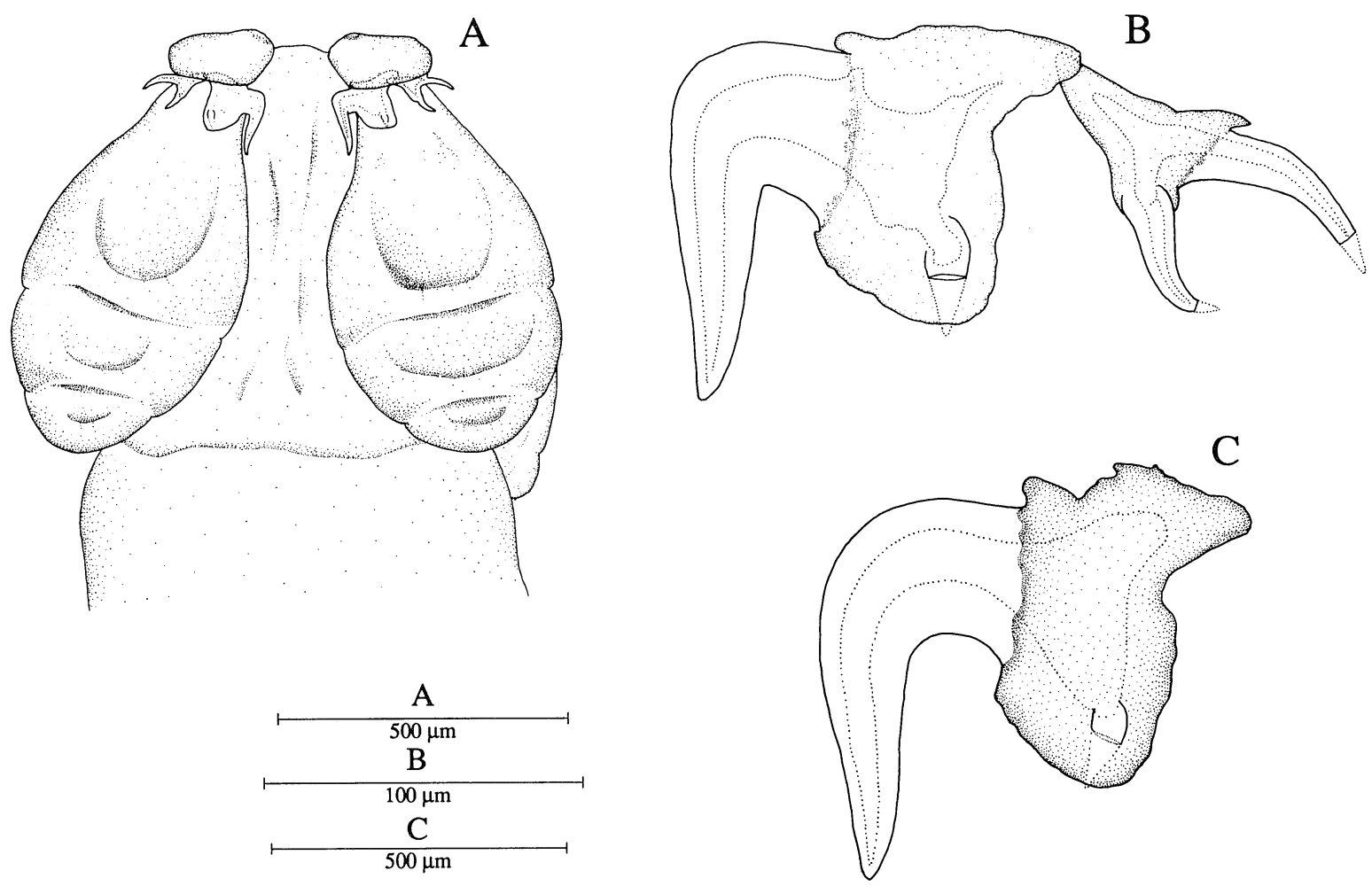

$\mathrm{D}$
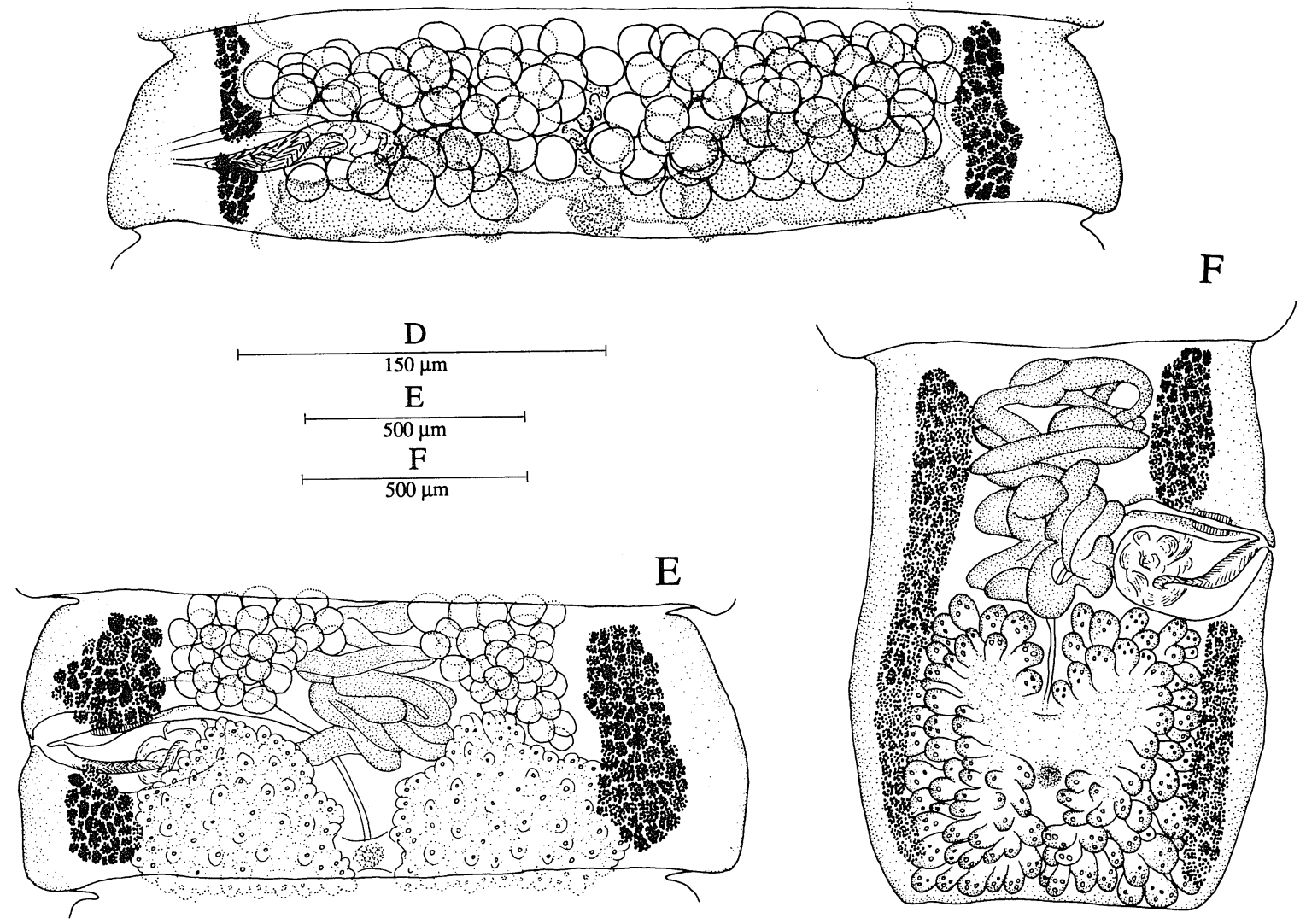

Figure 1. Acanthobothroides pacificus n. sp. and A. thorsoni. A. Scolex of A. pacificus n. sp. B. Medial and lateral hooks of $A$. pacificus n. sp. C. Medial hook of $A$. thorsoni (UNSMHWML no. 20259, paratype). D. Immature proglottis (dorsal lobe of ovary omitted) in $A$. pacificus n. sp. E. Mature proglottis with testes in A. pacificus n. sp. F. terminal proglottis without testes but with sperm in vas deferens in $A$. pacificus $\mathrm{n}$. sp. 
304 THE JOURNAL OF PARASITOLOGY, VOL. 82, NO. 2, APRIL 1996
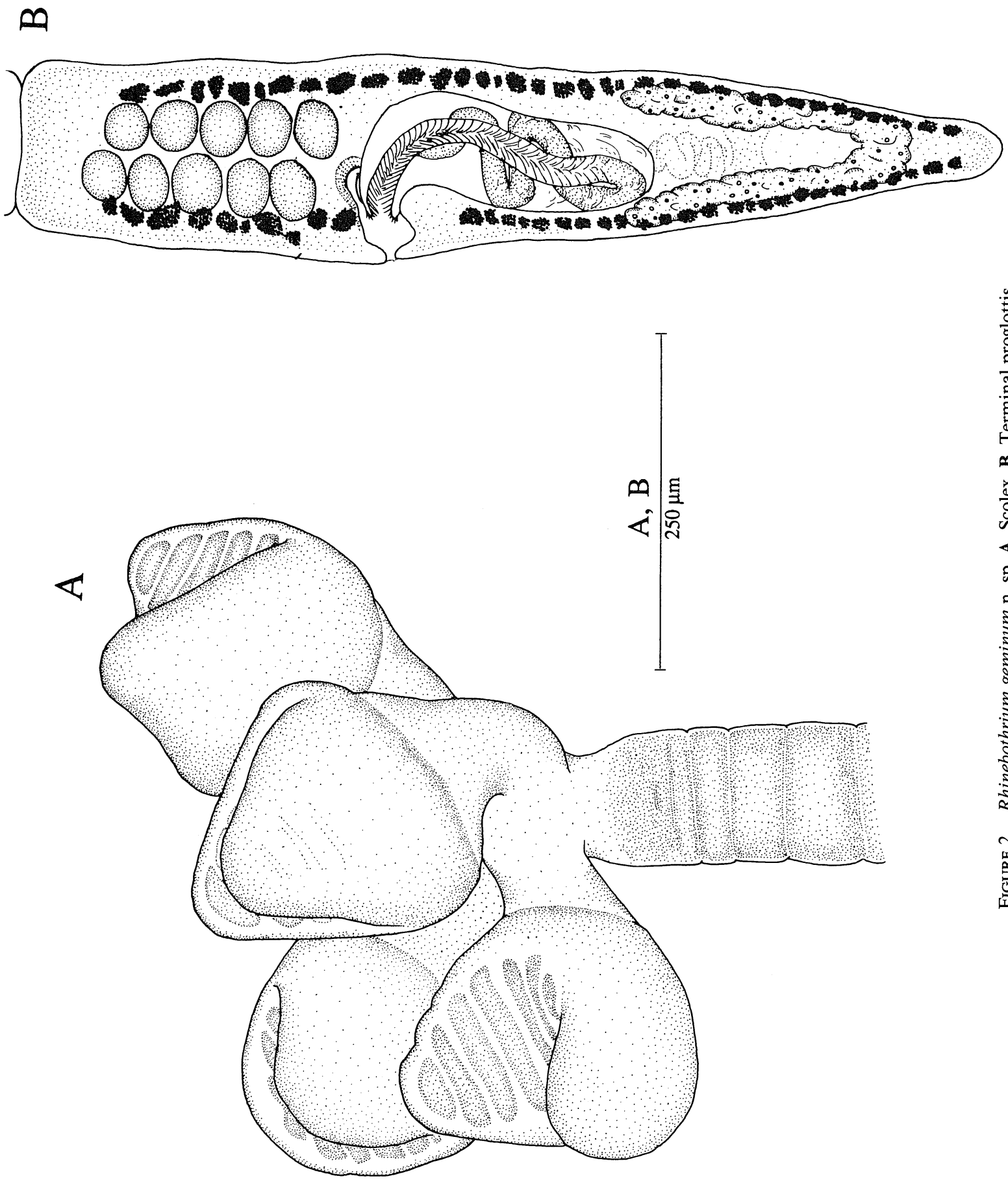

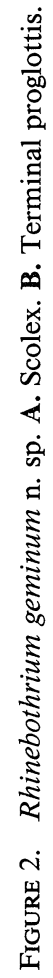


leces comprising 4 triloculate bothridia each surmounted by an apical pad and sucker and armed with a pair of hooks. The lateral hook was similar in shape to those exhibited by species of Acanthobothrium Van Beneden, 1849 and the medial hook described as having a single robust prong, thus distinct from other species of Acanthobothrium. Acanthobothroides pacificus is highly similar to $A$. thorsoni. Our specimens are smaller (up to $122 \mathrm{~mm}$ long) than those of $A$. thorsoni (up to $400 \mathrm{~mm}$ long) and have fewer segments (approximately 400 rather than 700). Mature proglottides of $A$. thorsoni are longer (852-876) than those of $A$. pacificus (394-604). The bothridia are nearly the same length in both species, but they are wider in $A$. pacificus than in $A$. thorsoni; in addition, $A$. pacificus possesses relatively shorter medial loculi and relatively longer posterior loculi than $A$. thorsoni (the ratio of bothiridial loculi lengths is 1:0.4:0.3 for $A$. pacificus and 1:0.5:0.2 for A. thorsoni). Acanthobothroides pacificus has smaller bothridial hooks (lateral hook 98-123 $\mu \mathrm{m}$ long, handle of medial hook 92-116 $\mu \mathrm{m}$ long) than $A$. thorsoni (lateral hook 168-198 $\mu \mathrm{m}$ long, handle of medial hook 162-168 $\mu \mathrm{m}$ long). Alternatively, $A$. pacificus possesses slightly more testes per proglottis (averaging 104, with a maximum of 125 ) than $A$. thorsoni (averaging 92, with a maximum of 97$)$. Finally, $A$. pacificus exhibits slightly smaller cirrus sacs (337-445 $\times 146-223)$ than $A$. thorsoni $(415-504 \times 180$ 240). Acanthobothroides pacificus is anapolytic, as is $A$. thorsoni. Euzet (1994) incorrectly listed $A$. thorsoni as euapolytic.

The specimens of $A$. thorsoni collected by Brooks (1977) had broken hook tips on the prongs of the lateral hook, a condition originally attributed to rough handling during collection of specimens strongly attached to the spiral valve. Consequently, specimens of $A$. pacificus, which were also very firmly attached to the host intestine, were removed with great care. Despite gentle handling, the tips of the hook prongs for the lateral hooks were missing in our specimens of $A$. pacificus; thus, we think this may be a normal condition in species of Acanthobothroides. Furthermore, during our examination of the medial hooks of $\mathrm{A}$. pacificus, we discovered a very small inner prong, also exhibiting a broken tip (Fig. 1B). Re-examination of the holotype (USNPC no. 73959) and 2 paratypes (UNSMHWML no. 20259) of $A$. thorsoni revealed a similar basal fragment of an inner prong on the medial hook (Fig. 1C). We believe that the presence of an inner prong on the medial hook with a broken tip is also a normal condition in both $A$. thorsoni and $A$. pacificus. We propose therefore that the generic diagnosis of Acanthobothroides be emended to reflect the observation that the medial hook has a robust outer prong and a minute inner prong. In the absence of a phylogenetic analysis of Acanthobothrium and Acanthobothroides, we can only speculate that the minute inner prong is a vestigial trait indicating close relationship with Acanthobothrium. We believe that the massive size of the outer prong of the medial hook may exert enough force during attachment to the host intestine that the tips of the much more delicate prongs of the lateral hooks and of the inner prong of the medial hook may be broken.

\section{Acanthobothroides Brooks, 1977}

Emended diagnosis: Onchobothriidae. Scolex with four sessile, triloculate bothridia each with apical sucker and pad armed with a pair of dissimilar hooks: lateral hooks bifid with handle, medial hook has a robust outer prong and a minute inner prong. Genital pores marginal, irregularly alternating. Ovary bilobed in frontal view, $\mathrm{X}$-shaped in cross section. Vitellaria follicular, in marginal area of proglottis. Parasites of elasmobranchs.

\section{Rhinebothrium geminum n. sp.}

$$
\text { (Fig. 2A-D) }
$$

Description (based on 16 specimens): Strobila acraspedote, anapolytic, 1.3-2.3 (1.7 $\pm 0.3 ; \mathrm{n}=14) \mathrm{mm}$ long; composed of 7-11 (9 \pm 1 ; $\mathrm{n}=16$ ) proglottides. Scolex composed of 4 pedicellated, bilobed, elongate bothridia; pedicels $62-126(92.6 ; \mathrm{n}=22)$ long; bothridia 252-378 $(331 \pm 44 ; n=6)$ long by $142-221(178 \pm 20 ; n=11)$ wide divided transversally by 11-13 transverse septa forming 12-14 total loculi; median longitudinal septum absent. Cephalic peduncle 76-126 (107 \pm 19 ; $\mathrm{n}=14) \mathrm{mm}$ long. Immature proglottides wider than long. Mature proglottides $528-782(662 \pm 67 ; n=13)$ long by $102-159(129 \pm 19 ; n=$ 9) wide. Tests restricted posteriorly to cirrus sac, 9-12 (11 $\pm 1 ; n=9)$ in number, and $25-48(33 \pm 5 ; n=35)$ in diameter. Cirrus sac extending posteriorly from mid-proglottis, $123-299(198 \pm 46 ; n=14)$ long by
63-113 $(73 \pm 17 ; n=9)$ wide, contained spined eversible cirrus. Vagina anterior to cirrus sac; vaginal sphincter a glandular thickening near genital pore. Genital pore $29-46 \%(37 \pm 4 ; n=12)$ of proglottis length from anterior end. Ovary V-shaped near posterior end of proglottis, lobes fused posteriorly, X-shaped in cross section, 195-378 (263 \pm 54 ; $\mathrm{n}=12)$ long by $60-94(74 \pm 11 ; n=9)$ wide at isthmus. Ovarian lobes symmetrical, extending anteriorly to 1 ovarian length posterior to level of genital pore, terminating just anterior to posterior margin of cirrus sac. Vitelline follicles extending entire length of proglottis, sometimes confluent posterior to ovary, $13-32(21 \pm 5 ; n=22)$ in diameter.

\section{Taxonomic summary}

Host: Himantura pacifica (Beebe and Tee-Van).

Site of infection: Spiral valve.

Locality: Playa Panama, Guanacaste, Costa Rica $\left(10^{\circ} 15^{\prime} \mathrm{N} ; 86^{\circ} 00^{\prime} \mathrm{W}\right)$.

Holotype: MNHG no. INV 20587.

Paratypes: MNHG no. INV 20588-9; UNSMHWML no. 38743.

Etymology: The specific epithet "geminum," meaning twin, refers to the high degree of similarity and apparent close relationship between the new species and Rhinebothrium magniphallum Brooks, 1977, inhabiting $H$. schmardae from the Atlantic coast of Colombia.

\section{Remarks}

Rhinebothrium geminum $\mathrm{n}$. sp. is a member of a phenetic grouping of 6 species of Rhinebothrium Linton, 1890 with bothridia lacking constrictions or "hinges" and divided into loculi by transverse septa only. This collection includes Rhinebothrium minimum (Van Beneden, 1850) Euzet, 1956 in Dasyatis pastinaca (L.) from France, Rhinebothrium shipleyi Southwell, 1911 in Trygon (= Dasyatis) kuhli (Müller and Henle) from Sri Lanka and Dasyatis akajei (Müller \& Henle) from Japan, Rhinebothrium palombii Baer, 1948 in Dasyatis violacea (Bonaparte) from the Mediterranean Sea, Rhinebothrium rankini Baer, 1948 in Dasyatis centroura (Mitchill) from the Atlantic coast of the United States, Rhinebothrium taeniuri Ramadan, 1984 in Taeniura lymma (Forskål) from the Red Sea, and $R$. magniphallum Brooks, 1977 in $H$. schmardae from the Caribbean coast of Colombia. Of these, only $R$. magniphallum shares with $R$. geminum the presumably apomorphic trait of a relatively large cirrus sac compared with other species of Rhinebothrium. In most species of Rhinebothrium, the genital pore is close to the level of the anterior extent of the ovary, and the cirrus sac fills the space between the genital pore and anterior extent of the ovary, which are close together. In $R$. geminum and $R$. magniphallum, the genital pore is separated from the anterior arms of the ovary by approximately 1 ovarian length, and the cirrus sac is enlarged enough to fill the available space between the genital pore and anterior extent of the ovary (Fig. 2B). Rhinebothrium geminum differs from $R$. magniphallum by having a smaller number of bothridial loculi (12-14) and smaller number of testes per proglottis (9-12) than $R$. magniphallum (16-18 loculi, $10-15$ testes). Of the other species listed above, $R$. minimum (4-5 testes, 11 loculi) and $R$. taeniuri (4-8 testes, 9-11 loculi) have fewer testes per proglottis and bothridial loculi (11) than $R$. geminum, whereas $R$. shipleyi (4144 testes, 20-23 loculi), $R$. rankini (50-55 testes, 23 loculi), and $R$. palombii (82-142 testes, 20-22 loculi) have more of each than $R$. geminum.

As stated above, Brooks (1977) described $R$. magniphallum in $H$. schmardae. Species of Rhinebothrium are thought to exhibit high degrees of specificity for their stingray hosts (e.g., Baer, 1948; Euzet, 1956; Campbell, 1970; Appy and Dailey, 1977). Thus, it was somewhat surprising for Brooks and Mayes (1980) to find $R$. magniphallum inhabiting Dasyatis americana Hildebrand and Schroeder, Urotrygon venezuelae Schultz, and Urolophus jamaicensis (Cuvier). If it is the sister species of $R$. magniphallum, subsequent studies might show that $R$. geminum also exhibits reduced host specificity.

\section{DISCUSSION}

Jordan (1908) coined the term "geminate" species referring to pairs of sister species occurring on opposite sides of some form of geographic barrier; he used the Panama isthmus as a classical example. Jordan pointed out that these species pairs differed from one another to only a minor degree, suggesting 
recent evolutionary divergence. More than half a century ago, Manter (1940) presented a list of putative geminate species pairs of digenetic trematodes inhabiting marine fishes living on each side of the isthmus. According to Lessios (1979), the completion of the Panamanian isthmus occurred between 3.5 to 5.7 million years ago and 2 million years ago, a relatively recent event. Many free-living taxa have been suggested as having geminate species representatives on each side of the isthmus (Voight [1988] for octopods, Lessios [1979] for sea urchins, Griffith [1987] for pinnotherid crabs of the genus Dissodactylus, and White [1986] for atherinid fishes).

Beebe and Tee-Van (1941) suggested that $H$. pacifica and $H$. schmardae are closely related on the basis of their general morphological similarity. Although overall similarity can be a misleading criterion for inferring sister group relationships, this hypothesis seems reasonable given that there are not other species of Himantura in the Caribbean Sea or the eastern Pacific. It is possible, therefore, that $H$. schmardae-H. pacifica, $A$. thorsoni-A. pacificus, and $R$. magniphallum-R. geminum are all geminate species pairs whose evolutionary origin resulted from the formation of the Panama isthmus barrier.

\section{ACKNOWLEDGMENTS}

We thank Nathan Lovejoy and Effie Gournis for their help in collecting hosts and parasites; Dr. Jose Vargas, Director of the Centro de Investigaciones en Ciencias del Mar y Limnologia (CIMAR); and the members of the faculty of the Escuela de Biología and Escuela de Microbiología, Universidad de Costa Rica. This study was funded by operating grant A7696 from the Natural Sciences and Engineering Council (NSERC) of Canada to D.R.B. and a CNPq (Federal Government of Brazil) doctoral fellowship to F.M.

\section{LITERATURE CITED}

APPY, R., AND M. D. DAILEY. 1977. A new species of Rhinebothrium (Cestoda: Tetraphyllidea) and redescription of three rhinebothriate species from the round stingray, Urolophus halleri Cooper in Southern California. Proceedings of the Southern California Academy of Sciences 76: 116-127.

BAER, J. G. 1948. Contributions à l'étude des cestodes de sélaciens. I-IV. Bulletin de la Société Neuchâteloise des Sciences naturelles 71: 63-122.

BeEbe, W., AND J. Tee-Van. 1941. Eastern Pacific Expeditions of the New York Zoological Society. XXVIII. Fishes from the tropical Eastern Pacific. [From Cedros Island, lower California, south of the Galápagos Islands and northen Peru.] Part 3. Rays, mantas and chimaeras. Zoologica 26: 245-280.

Brooks, D. R. 1977. Six new species of tetraphyllidean cestodes, including a new genus, from a marine stingray Himantura schmardae (Werner, 1904) from Colombia. Proceedings of the Helminthological Society of Washington 44: 51-59.

, AND M. A. MAYES. 1980. Cestodes from five species of Colombian euryhaline stingrays. Proceedings of the Helminthological Society of Washington 47: 22-29.

CAMPBell, R. A. 1970. Notes on tetraphyllidean cestodes from the Atlantic coast of North America with descriptions of two new species. Journal of Parasitology 56: 498-508.

EUZET, L. 1956. Recherches sur les cestodes tétraphyllides des sélaciens des côtes de France. Ph.D. Dissertation. University of Montpellier, Montpelier, France, 263 p.

. 1994. Order Tetraphyllidea. In Keys to the cestode parasites of vertebrates, L. F. Khalil, A. Jones, and R. A. Bray (eds.). University Press, Cambridge, U.K., p. 149-194.

Griffith, H. 1987. Phylogenetic relationships in the genus Dissodactylus Smith, 1870 (Crustacea: Brachyura: Pinnotheridae). Canadian Journal of Zoology 65: 2292-2310.

Jordan, D. S. 1908. The law of geminate species. American Naturalist 42: 73-80.

Lessios, H. A. 1979. Use of Panamanian sea urchins to test the molecular clock. Nature 280: 599-561.

MANTER, H. W. 1940. The geographical distribution of digenetic trematodes of marine fishes of the tropical American Pacific. The University of Southern California Publications. Allan Hancock Pacific Expeditions 2: 531-546.

VoIGHT, J. R. 1988. Trans-panamanian geminate octopods (Mollusca: Octopoda). Malacologia 29: 289-294.

White, B. N. 1986. The isthmian link, Antitropicality and American biogeography: Distributional history of the Atherinopsinae (Pisces: Atherinidae). Systematic Zoology 35: 176-194. 